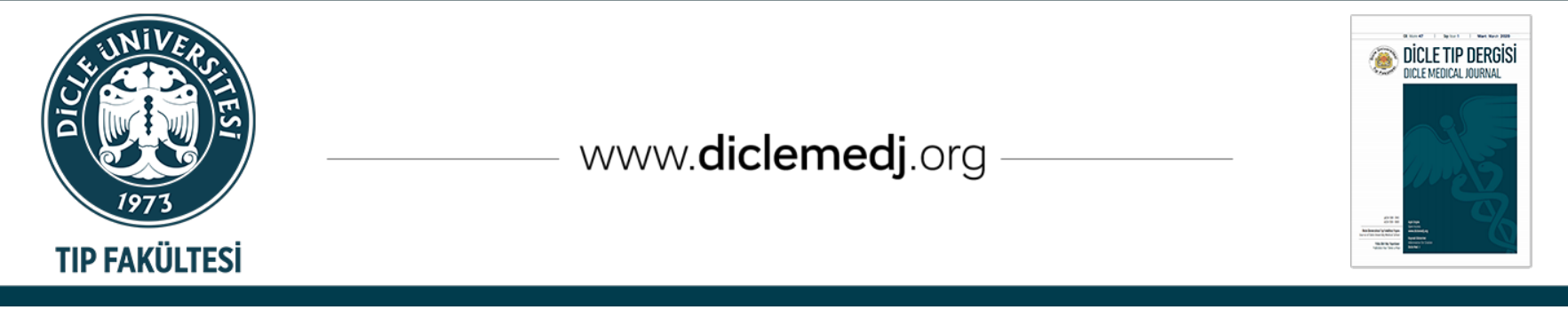

Özgün Araștırma / Original Article

\title{
Sağlık Çalışanlarının Kızamık, Kızamıkçık, Kabakulak ve Suçiçeği Geçirme ve Aşılanma Durumlarının Değerlendirilmesi (Ülke Geneli Çok Merkezli Çalışma)
}

\author{
Handan Alay ${ }^{(D)}$, Ayșe Ferdane Oğuzöncül $(i D)$, Ayșe Torun ${ }^{D}$ 3, Gülnur Kul ${ }^{\text {4 }}$, Selma Tosun 5 ,

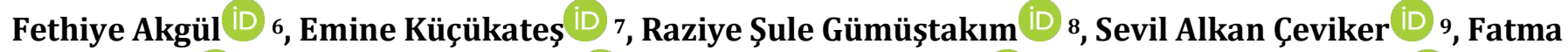 \\ Kesmez Can ${ }^{1}$, Asiye Bahar Kaçmaz ${ }^{10}$, Hüseyin Aytaç Erdem ${ }^{i}$ 11, Ebru Demiray Gürbüz ${ }^{12}$, Uğur \\ Kostakoğlu iD 13, Hilal Bölükbaşı iD 14, Nuray Kasar ${ }^{\text {iD }}$ 15, Emre Güven iD 16, Serap Pamukçuoğlu 17 \\ 1 Atatürk Üniversitesi Tıp Fakültesi, Enfeksiyon Hastalıkları ve Klinik Mikrobiyoloji Anabilim Dal, Erzurum, Türkiye \\ 2 Fırat Üniversitesi Tıp Fakültesi Halk Sağlı̆̆ı Anabilim Dalı, Elazığ, Türkiye \\ 3 Şanlıurfa EAH, Enfeksiyon Hastalıkları ve Klinik Mikrobiyoloji Kliniği, Şanlıurfa, Türkiye \\ 4 TC Sağlık Bakanlığı Kırıkhan Devlet Hastanesi, Enfeksiyon Hastalıkları ve Klinik Mikrobiyoloji Kliniği, Hatay, Türkiye \\ 5 SBÜ İzmir Bozyaka EAH, Enfeksiyon Hastalıkları ve Klinik Mikrobiyoloji Kliniği, İzmir, Türkiye \\ 6 TC Sağlık Bakanlı̆̆ı Batman Bölge Devlet Hastanesi, Enfeksiyon Hastalıkları ve Klinik Mikrobiyoloji Kliniği, Batman, Türkiye \\ 7 İstanbul Üniversitesi Cerrahpaşa Kardiyoloji Enstitüsü, Tıbbi Mikrobiyoloji Kliniği, İstanbul, Türkiye \\ 8 Kahramanmaraş Sütçü İmam Üniversitesi Tıp Fakültesi, Aile hekimliği Anabilim Dal, Kahramanmaraş, Türkiye \\ 9 Kütahya Sağlı Bilimleri Üniversitesi Evliya Çelebi EAH, Enfeksiyon Hastalıkları ve Klinik Mikrobiyoloji Kliniği, Kütahya, Türkiye \\ 10 Bezmialem Vaklf Üniversitesi Dragos Hastanesi, Enfeksiyon Hastalıkları ve Klinik Mikrobiyoloji Kliniği, İstanbul, Türkiye \\ 11 Ege Üniversitesi Tıp Fakültesi, Enfeksiyon Hastalıkları ve Klinik Mikrobiyoloji Kliniği, İzmir, Türkiye \\ 12 Dokuz Eylül Üniversitesi Tıp Fakültesi, Tıbbi Mikrobiyoloji, İzmir, Türkiye \\ 13 Recep Tayyip Erdoğan Üniversitesi Tıp Fakültesi, Enfeksiyon Hastalıkları ve Klinik Mikrobiyoloji Kliniği, Rize, Türkiye \\ 14 Ankara Şehir Hastanesi, Tıbbi Mikrobiyoloji, Ankara, Türkiye \\ 15 TC Sağlık Bakanlığı Kızıltepe Devlet Hastanesi, Enfeksiyon Hastalıkları ve Klinik Mikrobiyoloji, Mardin, Türkiye \\ 16 TC Sağlık Bakanlığı Beytepe Murat Erdi Eker Devlet Hastanesi, Enfeksiyon Hastalıkları ve Klinik Mikrobiyoloji, Ankara, Türkiye \\ 17 TC Sağlık Bakanlığı Afyon Devlet Hastanesi, Enfeksiyon Hastalıkları ve Klinik Mikrobiyoloji, Afyon, Türkiye \\ Geliş: 07.05.2020; Revizyon: 01.07.2020; Kabul Tarihi: 06.07.2020
}

DOI: 10.5798/dicletip.800273

Correspondence / Yazıșma Adresi: Handan Alay, Atatürk Üniversitesi Tıp Fakültesi, Enfeksiyon Hastalıkları ve Klinik Mikrobiyoloji Anabilim Dall, Erzurum, Türkiye e-mail: alayhandan@gmail.com 


\title{
Öz
}

Giriş: Kızamık, kızamıkçık, kabakulak (KKK) ve suçiçeği hastalıkları aşı ile önlenebilir hastalıklar arasında yer almaktadır. Sağlık çalışanlarının enfeksiyon hastalıklarına karşı bağıșıklık ve aşılanma durumlarının bilinmesi, duyarlı personelin belirlenmesi ve ardından uygun aşllama programlarının geliștirilmesi enfeksiyonların önlenmesi ve kontrolü için önemlidir.

Amaç: Ülke genelini kapsayan çok merkezli olarak gerçekleştirilen bu çalışmada, KKK ve suçiçeği gibi döküntülü hastalıklarla karşılaşma riski fazla olan sağlık çalışanlarının hastalık geçirme, test yaptırma ve aşılanma durumlarının belirlenmesi amaçlanmıştır.

Yöntemler: Sağlık çalışanlarının demografik özelliklerini, KKK ve suçiçeği hastalığını geçirme ve aşılanma durumlarını öğrenmeye yönelik bir anket formu oluşturulmuş ve bu form web sayfası üzerinden online ulaşılabilen bir link aracılığıyla sağlık çalışanlarına iletilerek katılımcıların anketteki soruları yanıtlamaları istenmiştir.

Bulgular: Çalışmaya Türkiye'de toplam yedi bölgeden 12.475 sağlık çalışanı katıldı. Katılımcıların 8099 (\%64,9)’u kadın, 4376 $(\% 35,1)$ 'i erkek ve yaş ortalaması 35.4 9.4 yıl idi. KKK ve suçiçeği geçirmeme durumları \%22,4-34,9 arasında idi. Sağlık çalışanlarının KKK ve suçiçeği aşılanma durumları sorgulandı. KKK için katılımcıların \%22,3'ü (n=2784), suçiçeği aşısı için katılımcıların \%22'si (n=2748) bu soruya cevap vermedi. KKK ve suçiçeği aşısı yaptıranlar sırasıyla $2048(\% 21,1)$ ve 4451 (\%45,8) idi. KKK ve suçiçeği serolojisi baktırmayan sağlı çalışanlarının sayısı sırasıyla 8953 (\%79), 9010 (\%80,1), 9363 (\%83,5) ve 9591 (\%85,4) idi. Kızamık IgG serolojisi baktıran 2383 kișiden \%77,6'sı kızamık IgG pozitif, 2233 kişinin \%81,5'i kızamıkçı IgG pozitif, 1854 kişinin \%81.6'sı kabakulak IgG pozitif ve 1644 kişinin \%83,6'sı suçiçeği IgG sonucu pozitifdi. Katılımcıların cinsiyet, yaş ve meslek gruplarına göre KKK ve suçiçeği așısı yaptırma durumları değerlendirildiğinde istatiksel anlamlılık yoktu (p>0.05).

Sonuç: Çalışmamızda serolojik sonuçlarına baktırmayan sağlık çalışanlarının oranının fazla olması ülke genelinde bu konudaki eksiklikleri ön plana çıkarmaktadır. Sağlık çalışanlarının serolojik değerlendirmeleri işe başlamadan önce kontrol edilmeli ve gerekli aşı programına alınmalıdır.

Anahtar kelimeler: sağlık çalışanı, kızamık-kızamıkçık-kabakulak, suçiçeği, aşı

\section{An Evaluation of Health Workers' Measles, Rubella, Mumps, and Chickenpox Infection and Vaccination Status (A Nationwide Multi-Center Study)}

\begin{abstract}
Objective: Measles, rubella, mumps (MRM) and chickenpox are diseases that can be prevented by vaccination. Knowledge of health workers' immunity to infectious diseases and vaccination status, the identification of susceptible individuals, and subsequent appropriate vaccination programs are essential to the prevention and control of infections.
\end{abstract}

Aim: The purpose of this nationwide multi-center study was to investigate the infection, testing, and vaccination status of health workers, individuals at greater risk of encountering exanthematous diseases such as MRM and chickenpox.

Method: A questionnaire intended for eliciting health workers' demographic characteristics, MRM and chickenpox infection, and vaccination status was produced, and participants were asked to respond with the form being dispatched through a link available online via the web page.

Results: A total of 12,475 health workers from the seven regions of Turkey participated, 8099 participants (64.9\%) women and 4376 (35.1\%) men, with a mean age of 35.4 9.4 years. Infection rates for measles, rubella, mumps, and chickenpox ranged between $22.4 \%$ and $34.9 \%$. Health workers' MRM and chickenpox vaccination status was investigated, with $22.3 \%$ (n=2784) not answering that question for MRM vaccination, and 22\% ( $n=2748)$ not responding for chickenpox vaccination. Numbers of participants vaccinated against MRM and chickenpox performed were 2048 (21.1\%) and 4451 (45.8\%), respectively. Numbers of health workers not having measles, rubella, mumps or chickenpox serological tests performed were 8953 (79\%), 9010 (80.1\%), 9363 (83.5\%), and 9591 (85.4\%). Of the 2383 individuals having measles IgG serological tests performed, $77.6 \%$ were measles IgG positive, $81.5 \%$ of 2233 individuals were rubella IgG positive, $81.6 \%$ of 1854 participants were rubella IgG positive, and $83.6 \%$ of 1644 participants were chickenpox IgG positive. No statistically significant associations were determined between participants' age, sex, or occupational group and MRM and chickenpox vaccination status ( $\mathrm{p}>0.05)$.

Conclusion: The high rates of health workers not having serological tests performed in this study indicates a weakness in this area in Turkey as a whole. Serological examinations should be performed before health workers commence employment, and they must be enrolled in the appropriate vaccination programs.

Keywords: health worker, measles-rubella-mumps, chickenpox, vaccination. 


\section{GíRiş}

Sağlık çalışanları bir çok enfeksiyon hastalığı bulaşması açısından risk altındadır. Bunların bazıları aşıyla korunulabilen hastalıklardır. Bunun yanı sıra hastalar da bağışıklığı olmayan sağlık çalışanından olası bulaş yönüyle etkilenebilmektedir. $\mathrm{Bu}$ nedenle sağlık çalışanlarının aşılanması, hem sağlık çalışanlarının hem de hastaların aşı ile önlenebilir hastalıklardan korunmasında oldukça önemlidir ${ }^{1}$. Ülke genelinde yapılan aşı programlarının iyi yönetilmesi hem duyarlı sağlık çalışanlarını aşı ile önlenebilir hastalıklara karşı koruyacak hem de sağlık çalışanlarından diğer personele ve hastalara bulaş riskini önemli ölçüde azaltacaktır².

Kızamık, kızamıkçık, kabakulak (KKK) ve suçiçeği hastalıkları aşı ile önlenebilir hastalıklar arasında yer almaktadır. Sağlık çalışanlarının enfeksiyon hastalıklarına karşı bağışıklık ve aşılanma durumlarının bilinmesi, duyarlı personelin belirlenmesi ve ardından uygun aşılama programlarının yapılması enfeksiyonların önlenmesi ve kontrolü için gereklidir ${ }^{2,3}$.

Aşı uygulamaları öneri komitesi (The Advisory Committee on Immunization Practices; ACIP) sağlık kurumlarında çalışan tüm personelin KKK ve suçiçeğine karşı bağışıklık durumunun bilinmesini ve bağışıklığı olmayan sağlık çalışanlarına da KKK ve suçiçeği aşısı yapılmasını önermektedir ${ }^{1}$. Ülkemizde birçok aşı sağlık çalışanlarına ücretsiz yapılmaktadır ancak hepatit B, hepatit $A$ ve tetanoz aşısı dışındaki aşılarla aşılanma düzeyleri hakkında bilgilerimiz yeterli değildir. Ülke genelini kapsayan çok merkezli olarak gerçekleştirilen bu çalışmada, KKK ve suçiçeği gibi döküntülü hastalıklarla karşılaşma riski fazla olan sağlık çalışanlarının hastalık geçirme, tetkik yaptırma ve aşılanma durumlarının araştırılması amaçlanmıştır.

\section{YÖNTEMLER}

Sağllk Bilimleri Üniversitesi İzmir Bozyaka Eğitim Araştırma Hastanesi Etik kurulu (Tarih: 08.09.2016 Sayı : 461) onayı ve Türkiye Halk Sağlığı Kurumu iznini takiben, ülke genelinde çok merkezli olarak online anket şeklinde gerçekleştirilen tanımlayıcı nitelikte bir araştırmadır. Çalışmamızın ilk bölümü 2 Ocak - 30 Kasım 2017 tarihleri arasında, katılımı arttırabilmek amacıyla ikinci bölümü de 2 Şubat - 30 Haziran 2019 tarihleri arasında tamamlanmıştır. Bu süre içinde Türkiye'nin tüm bölgelerinden katılım sağlanarak gerçekleştirilmiştir. (Resim 1). Sağlık çalışanlarının demografik özelliklerini, KKK ve suçiçeği hastalığını geçirme ve aşılanma durumlarını öğrenmeye yönelik bir anket formu oluşturulmuş ve bu form web sayfası üzerinden online ulaşllabilen bir link aracilığıyla sağlık çalışanlarına iletilerek katılımcıların anketteki soruları yanıtlamaları istenmiștir.

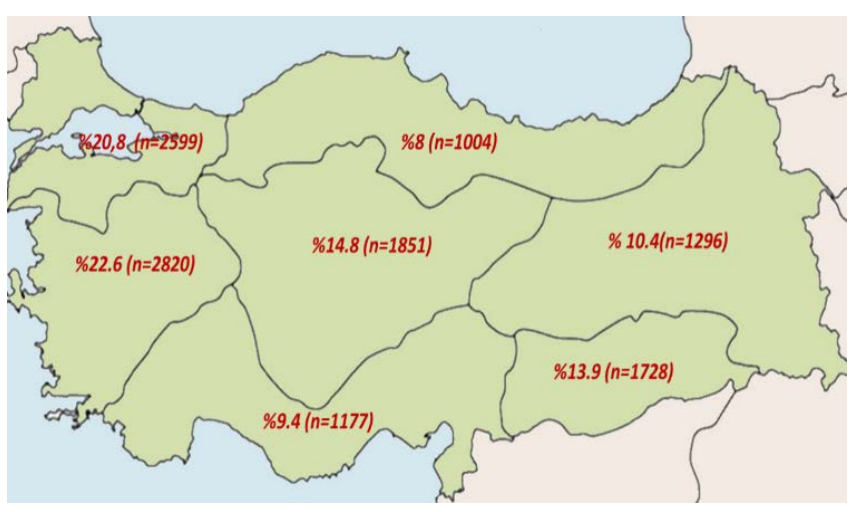

Resim 1. Katılımcıların Türkiye'de Bulunduğu Bölgeler

\section{İstatiksel Analiz}

Çalışmada elde edilen verilerin istatistiksel değerlendirmesinde SPSS 22.0 paket programı kullanılmıştır (Statistical Package for the Social Sciences Inc, Chicago, IL, ABD). Sürekli veriler ortalama, standart sapma şeklinde özetlenirken, kategorik veriler sayı ve yüzde cinsinden özetlenmiştir.

\section{BULGULAR}

Türkiye'de toplam yedi bölgeden 12.475 sağllk çalışanının katıldığı katılımcılara ait demografik özellikler tablo 1'de yer almaktadır. Katılımcılara KKK ve suçiçeği hastalıklarını geçirip geçirmedikleri durumu sorgulandi. Elde edilen sonuçlar tablo 2'de sunuldu. 
Tablo I: Katılımcıların Demografik Özellikleri

\begin{tabular}{|c|c|}
\hline \multicolumn{2}{|l|}{ Demografik özellikler } \\
\hline Cinsiyet & n (\%) \\
\hline Erkek & $4376(35,1)$ \\
\hline Kadın & $8099(64,9)$ \\
\hline Toplam & 12475 \\
\hline Yaş (ort \pm SD) (yıl) & $35.4 \pm 9.4$ yll (16-76) \\
\hline Eğitim durumu & n (\%) \\
\hline İlkokul & $20(0,2)$ \\
\hline Ortaokul & $262(2,1)$ \\
\hline Lise & $299(2,4)$ \\
\hline Üniversite - Yüksek Okul & $8825(70,7)$ \\
\hline Diğer & $3069(24,6)$ \\
\hline Toplam & 12475 \\
\hline Meslek grupları & n (\%) \\
\hline \multicolumn{2}{|l|}{ Hekim } \\
\hline Doçent-Profesör & $263(2,1)$ \\
\hline Yardımcı Doçent & $135(1,1)$ \\
\hline Aile hekimliği uzmanı & $55(0,4)$ \\
\hline Uzman hekim & $2062(16,5)$ \\
\hline Pratisyen hekim (TSM) & $197(1,6)$ \\
\hline Aile hekimi & $270(\% 2,2)$ \\
\hline Aile hekimliği asistanı & $144(1,2)$ \\
\hline Asistan & $619(5)$ \\
\hline Pratisyen Hekim & $98(0,8)$ \\
\hline \multicolumn{2}{|l|}{ öğrenci/stajyer } \\
\hline Tıp Fakültesi Öğrencisi & $713(5,7)$ \\
\hline Tıp dışı stajyer öğrenci & $360(2,9)$ \\
\hline \multicolumn{2}{|l|}{ Hekim dışı sağlık çalışanları } \\
\hline Diş hekimi & $54(0,4)$ \\
\hline Eczacı & $85(0,7)$ \\
\hline Hemşire-ebe & $4011(32,2)$ \\
\hline \multicolumn{2}{|l|}{ Laboratuvar çalışanı/Tıbbi teknisyen } \\
\hline \multicolumn{2}{|l|}{ Riski yüksek olanlar } \\
\hline $\begin{array}{l}\text { Laboratuvar teknisyeni (Mikrobiyoloji- } \\
\text { Biyokimya- Patoloji) }\end{array}$ & $410(3,3)$ \\
\hline $\begin{array}{l}\text { Riski düşük olanlar } \\
\text { Sağlık teknisyeni (Anestezi, Radyoloji, } \\
\text { Nükleer tıp ve diğer birimlerde çalışan) }\end{array}$ & $508(4,1)$ \\
\hline \multicolumn{2}{|l|}{ Temizlik şirketi çalışanları } \\
\hline Temizlik şirketi çalıșanı & $575(4,6)$ \\
\hline Hasta taşıma elemanı & $173(1,4)$ \\
\hline \multicolumn{2}{|l|}{ Büro çalışanı } \\
\hline Veri kayıt elemanı & $698(5,6)$ \\
\hline Büro çalışanı & $303(2,4)$ \\
\hline \multicolumn{2}{|l|}{ Diğer } \\
\hline $\begin{array}{l}\text { (Psikolog,diğer tıbbi teknisyen, mutfak, } \\
\text { şoför, ögretmen, atölye çalışanları, güvenlik, } \\
\text { yüksek lisans-doktora) }\end{array}$ & $742(6)$ \\
\hline Toplam & 12475 \\
\hline
\end{tabular}

Katılımcılara KKK ve suçiçeği hastalıklarını geçirip geçirmedikleri durumu sorgulandı. Elde edilen sonuçlar tablo 2'de sunuldu.

Tablo II: Sağlık Çalışanlarının Bildirdiği KKK ve Suçiçeği Geçirme Durumları

\begin{tabular}{|c|c|c|c|c|c|}
\hline $\begin{array}{c}\text { Hastalık } \\
\text { adı }\end{array}$ & $\begin{array}{c}\text { Geçirmedi } \\
\text { mn (\%) }\end{array}$ & $\begin{array}{l}\text { Hatirlamiy } \\
\text { orumn } \\
(\%)\end{array}$ & $\begin{array}{l}\text { Çocukken } \\
\text { geçirdiğimi } \\
\text { ailem } \\
\text { söyledi } \\
\text { n (\%) }\end{array}$ & $\begin{array}{c}\text { Çocukken } \\
\text { geçirdim } \\
\text { n (\%) }\end{array}$ & $\begin{array}{c}\text { Erişkin } \\
\text { yaşta } \\
\text { geçirdim } \\
\text { n (\%) }\end{array}$ \\
\hline $\begin{array}{l}\text { Kızamık } \\
\text { (n:12297) }\end{array}$ & $3499(28,5)$ & $4045(32,9)$ & $1947(15,8)$ & $2752(22,4)$ & $54(0,4)$ \\
\hline $\begin{array}{l}\text { Kızamıkçık } \\
\text { (n:12298) }\end{array}$ & $4297(34,9)$ & $5168(42)$ & $1303(10,6)$ & $1490(12,1)$ & $40(0,3)$ \\
\hline $\begin{array}{l}\text { Kabakulak } \\
\text { (n:12291) }\end{array}$ & 3194 (26) & $3249(26,4)$ & $2184(17,8)$ & 3559 (29) & $105(0,8)$ \\
\hline $\begin{array}{l}\text { Suçiçeği } \\
\text { (n:12305) }\end{array}$ & $2762(22,4)$ & $3160(25,7)$ & $2490(20,2)$ & $3725(30,3)$ & $168(1,4)$ \\
\hline
\end{tabular}

Sağlık çalışanlarının KKK ve suçiçeği aşısı yaptırıp yaptırmama durumları sorgulandı. KKK için katılımcların \%22,3'ü (n=2784), suçiçeği aşısı için katılımcların \%22'si $(n=2748)$ bu soruya cevap vermemiștir. Cevap veren katılımcıların sonuçları tablo 3'de verildi.

Tablo III: Sağlık Çalışanlarının Bildirdiği KKK ve Suçiçeği Așısı Yaptırma Durumu

\begin{tabular}{|c|c|c|c|c|c|c|}
\hline & $\begin{array}{c}\text { Așı } \\
\text { Yaptır } \\
\text { dım } \\
\text { n (\%) }\end{array}$ & $\begin{array}{c}\text { Așı } \\
\text { Yaptırma } \\
\text { dım } \\
\text { n (\%) }\end{array}$ & $\begin{array}{c}\text { Hatırlamıy } \\
\text { orum } \\
\text { n (\%) }\end{array}$ & $\begin{array}{c}\text { Sadece } \\
\text { Kızamı } \\
\text { k aşısı } \\
\text { yaptır } \\
\text { dım } \\
\text { n (\%) }\end{array}$ & $\begin{array}{c}\text { Sadece } \\
\text { Kızamı } \\
\text { kçık } \\
\text { aşıSı } \\
\text { yaptırdı } \\
\text { m } \\
\text { n (\%) }\end{array}$ & $\begin{array}{c}\text { Bağışık } \\
\text { olduğum } \\
\text { için } \\
\text { yaptırma } \\
\text { dım } \\
\text { n (\%) }\end{array}$ \\
\hline $\begin{array}{l}\text { KKK } \\
\text { Așis1 } \\
\text { (n:96 } \\
91)\end{array}$ & $\begin{array}{c}2713 \\
(28)\end{array}$ & $\begin{array}{c}2048 \\
(21,1)\end{array}$ & $4262(44)$ & $\begin{array}{c}140 \\
(1,4)\end{array}$ & $41(0,4)$ & $487(5)$ \\
\hline $\begin{array}{l}\text { Suçiçe } \\
\text { ği } \\
\text { Aşısı } \\
\text { (n:97 } \\
27 \text { ) }\end{array}$ & 785 (8) & $\begin{array}{c}4451 \\
(45,8)\end{array}$ & $3658(37,6)$ & - & - & $833(8,6)$ \\
\hline
\end{tabular}

Katılımcılara herhangi bir zamanda KKK ve Suçiçeği ile ilgili olarak tetkik yaptırıp yaptırmadıkları sorgulandı. 11336 katılımcıdan 2383 (\%21)'ü kızamık serolojisi baktırdığını, 11243 kişiden 2233 (\%19,9)'ü kızamıkçık serolojisi baktırdığını, 11217 kişinin $1854 \quad(\% 16,5)^{\prime} \ddot{\text { u }}$ kabakulak serolojisi baktırdığını ve 11235 kişiden 1644 (\%14,6)'ü suçiçeği serolojisi baktırdığını ifade etti. 
Tablo IV: Cinsiyet ve Yaşa Göre KKK ve Suçiçeği Aşısı Yaptırma Durumları

\begin{tabular}{|c|c|c|c|c|c|c|c|c|c|}
\hline & & & & \multicolumn{3}{|c|}{ Cinsiyet } & \multicolumn{3}{|c|}{ Yaş Aralığı } \\
\hline & & & & Erkek & Kadın & $\mathrm{p}$ & $<40$ yaş & $\geq 40$ yaş & $\mathrm{p}$ \\
\hline \multirow{6}{*}{$\begin{array}{l}\text { KKK } \\
\text { Yaptırma } \\
\text { Durumu }\end{array}$} & \multirow{6}{*}{ Aşısı } & Yaptırmadım & $\mathrm{n}(\%)$ & $956(35,2)$ & $1757(64,5)$ & \multirow{6}{*}{0,12} & $1781(65,6)$ & $932(34,4)$ & \multirow{6}{*}{0,23} \\
\hline & & Yaptırdım & $\mathrm{n}(\%)$ & $734(35,8)$ & $1314(64,2)$ & & $1346(65,7)$ & $702(34,3)$ & \\
\hline & & Hatırlamıyorum & $\mathrm{n}(\%)$ & $1479(34,7)$ & $2783(65,3)$ & & $2694(63,2)$ & $1568(36,1)$ & \\
\hline & & Sadece kızamık yaptırdım & $\mathrm{n}(\%)$ & $62(44,3)$ & $78(55,7)$ & & $89(63,6)$ & $51(36,4)$ & \\
\hline & & $\begin{array}{l}\text { Sadece kızamıkçık aşısı } \\
\text { yaptırdım. }\end{array}$ & $\mathrm{n}(\%)$ & $18(43,9)$ & $23(56,1)$ & & $25(619$ & $16(39)$ & \\
\hline & & $\begin{array}{l}\text { Bu hastalıklardan herhangi } \\
\text { birini geçirdiğim için } \\
\text { yaptırmadım }\end{array}$ & $\mathrm{n}(\%)$ & $186(38,2)$ & $301(61,8)$ & & $322(66,1)$ & $165(33,9)$ & \\
\hline \multirow{4}{*}{$\begin{array}{l}\text { Suçiçeği } \\
\text { Yaptırma } \\
\text { Durumu }\end{array}$} & Aşısı & Yaptırmadım & $\mathrm{n}(\%)$ & $1595(35,8)$ & $2856(64,2)$ & \multirow{4}{*}{0,78} & $2898(65,1)$ & $1553(34,9)$ & \multirow{4}{*}{0,61} \\
\hline & & Yaptırdım & $\mathrm{n}(\%)$ & $271(34,5)$ & $514(65,5)$ & & $501(63,8)$ & $284(36,2)$ & \\
\hline & & Hatırlamıyorum & $\mathrm{n}(\%)$ & $1279(35)$ & $2379(65)$ & & $2345(64,1)$ & $1313(35,9)$ & \\
\hline & & $\begin{array}{l}\text { Hastalığı geçirdiğim için } \\
\text { yaptırmadım }\end{array}$ & $\mathrm{n}(\%)$ & $300(36)$ & $533(64)$ & & $526(63,1)$ & $307(36,9)$ & \\
\hline
\end{tabular}

Tablo V: Meslek Gruplarına Göre KKK ve Suçiçeği Așısı Yaptırma Durumları

\begin{tabular}{|c|c|c|c|c|c|c|c|c|c|c|c|c|}
\hline \multicolumn{13}{|c|}{ Meslek Grupları } \\
\hline & & & 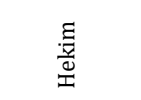 & 悐 & $\begin{array}{l}\overline{\widetilde{N}} \\
\underset{\sim}{\mathbb{I}}\end{array}$ & : & 宩菉 & 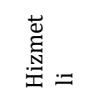 & $\underset{\Xi}{\Xi}$ & 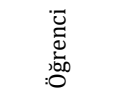 & 离 & ص \\
\hline \multirow{6}{*}{$\begin{array}{l}\text { MMR Așısı } \\
\text { Yapıldımı }\end{array}$} & Yaptırmadım & $\begin{array}{l}\mathrm{n} \\
(\%)\end{array}$ & $830(30,6)$ & $13(0,5)$ & $17(0,6)$ & $824(30,4)$ & $198(7,3)$ & $161(5,9)$ & $294(10,8)$ & $290(10,7)$ & $86(3,2)$ & \multirow{6}{*}{0,058} \\
\hline & Yaptırdım & $\begin{array}{l}\text { n } \\
\text { (\%) }\end{array}$ & $614(30)$ & $11(0,5)$ & $17(0,8)$ & $683(33,3)$ & $149(7,39$ & $126(6,2)$ & $195(9,5)$ & $176(8,6)$ & $77(3,8)$ & \\
\hline & $\begin{array}{l}\text { Hatırlamiyor } \\
\text { um }\end{array}$ & $\begin{array}{l}\mathrm{n} \\
(\%)\end{array}$ & $1314(30,8)$ & $19(0,4)$ & $23(0,5)$ & $1319(30,9)$ & $369(8,7)$ & $304(7,1)$ & $401(9,4)$ & $378(8,9)$ & $135(3,2)$ & \\
\hline & $\begin{array}{l}\text { Sadece } \\
\text { kızamık } \\
\text { yaptırdım }\end{array}$ & $\begin{array}{l}\mathrm{n} \\
(\%)\end{array}$ & $36(25,7)$ & - & - & $38(27,1)$ & $14(10)$ & $14(10)$ & $11(7,9)$ & $22(15,7)$ & $5(3,6)$ & \\
\hline & $\begin{array}{l}\text { Sadece } \\
\text { kızamıkçık } \\
\text { aşısı } \\
\text { yaptırdım. }\end{array}$ & $\begin{array}{l}\mathrm{n} \\
(\%)\end{array}$ & $14(34,1)$ & - & - & $14(34,1)$ & $2(4,9)$ & $2(4,9)$ & $3(7,3)$ & $3(7,3)$ & $3(7,3)$ & \\
\hline & $\begin{array}{l}\mathrm{Bu} \\
\text { hastalıklarda } \\
\mathrm{n} \quad \text { herhangi } \\
\text { birini } \\
\text { geçirdiğim } \\
\text { için } \\
\text { yaptırmadım }\end{array}$ & $\begin{array}{l}\mathrm{n} \\
(\%)\end{array}$ & $166(34,1)$ & $2(0,4)$ & $3(0,69$ & $137(28,1)$ & $48(9,9)$ & $27(5,5)$, & $43(8,8)$ & $39(8)$ & $22(4,5)$ & \\
\hline \multirow{4}{*}{$\begin{array}{l}\text { Suçiçeği } \\
\text { Așısı } \\
\text { Yaptırdını } \\
\text { zmı }\end{array}$} & Yaptırmadım & $\begin{array}{l}\mathrm{n} \\
(\%)\end{array}$ & $1390(31,2)$ & $19(0,4)$ & $27(0,6)$ & $1378(31)$ & $325(7,3)$ & $299(6,7)$ & $436(9,8)$ & $436(9,8)$ & $141(3,2)$ & \multirow{4}{*}{0,55} \\
\hline & Yaptırdım & $\begin{array}{l}\mathrm{n} \\
(\%)\end{array}$ & $224(28,5)$ & $2(0,3)$ & $5(0,6)$ & $257(32,7)$ & $60(7,6)$ & $53(6,8)$ & $85(10,8)$ & $69(8,8)$ & $30(3,8)$ & \\
\hline & $\begin{array}{l}\text { Hatırlamiyor } \\
\text { um }\end{array}$ & $\begin{array}{l}\mathrm{n} \\
(\%)\end{array}$ & $1130(30,9)$ & $21(0,6)$ & $24(0,7)$ & $1131(30,9)$ & $317(8,7)$ & $244(6,7)$ & $336(9,2)$ & $352(9,6)$ & $103(2,8)$ & \\
\hline & $\begin{array}{l}\text { Hastalığı } \\
\text { geçirdiğim } \\
\text { için } \\
\text { yaptırmadım }\end{array}$ & $\begin{array}{l}\mathrm{n} \\
(\%)\end{array}$ & $245(29,4)$ & $4(0,5)$ & $7(0,8)$ & $247(29,7)$ & $83(10)$ & $46(5,5)$ & $88(10,6)$ & $72(8,6)$ & $41(4,9)$ & \\
\hline
\end{tabular}


Kızamık IgG serolojisi baktıran 2383 kişiden \%77,6'sı kızamık IgG pozitif, 2233 kişinin \%81,5'i kızamıkçık IgG pozitif, 1854 kişinin \%81,6'sı kabakulak IgG pozitif ve 1644 kişinin \%83,6'sı suçiçeği IgG sonucu pozitifdi.

Katılımcıların cinsiyet, yaş ve meslek gruplarına göre KKK ve suçiçeği aşısı yaptırma durumları tablo 4 ve 5 'de yer almaktadır.

\section{TARTIŞMA}

Sağlık çalışanları için aşı programlarının düzenlenmesi enfeksiyonların önlenmesi ve kontrolünün önemli bir parçasıdır. Sağlık çalışanlarının akut olarak geçirdikleri enfeksiyon hastalıkları hem kendileri için hem de sağlık çalışanlarına ve bakım verdikleri hastalar için oldukça önem arz etmektedir. Bu nedenle sağlık çalışanlarının aşı ile önlenebilen hastalıklar için bağışıklık durumlarının test edilmesi (serolojik sonuçları) ve yapılan aşıların belgelenmesi gerekmektedir. Ancak sağlık çalışanlarının aşı ile önelenebilir enfeksiyon hastalıklarına karşı aşılanma durumları ve bu etkenler ile karşılaşma durumlarını belirleyen serolojik tetkik yaptırmaları her kurumda düzenli olarak yapılmamaktadır. Ülke genelinde çok sayıda sağlık çalışanının katılımının sağlandığı bu çalışma sonuçlarının hem ulusal ve hem de sağlık kurumlarının aşılama programlarına katkı sağlayacağını düşünmekteyiz.

Kızamık solunum damlacıkları ve hava yoluyla yayılan oldukça bulaştırıcı bir döküntülü hastalıktır. Maruziyet risklerinin daha fazla olması nedeniyle de sağlık çalışanlarının kızamığa yakalanma riskleri genel popülasyondan daha yüksektir ${ }^{2}$. Kabakulak enfeksiyonunun sağlık bakımı ile ilişkisi nadirdir fakat hastalığın asemptomatik geçirilme oranının (\%20-40) yüksek olması nedeniyle bildirimler yetersiz olabilmektedir. Ayrıca ileri yaşlarda geçirildiğinde erkekler için orşit ve takiben infertilite komplikasyonu söz konusudur. Döküntü, subfebril ateş, lenfadenopati ve halsizlik ile karakterize olan kızamıkçık hastalığında olguların \%25-50’si asemptomatik seyreder. Ancak gebelik sırasında geçirilen kızamıkçık enfeksiyonunun konjenital rubella sendromuna yol açma riski vardır ${ }^{4}$. Ülkemizde yapılan bir çalışmada doğurganlık çağındaki kadınlarda yüksek oranda rubella seropozitifliği saptanmıştır ${ }^{5}$. Bir çok döküntülü hastalık kızamıkçık enfeksiyonunu taklit edebilir. $\mathrm{Bu}$ durumda önceden kızamıkçık enfeksiyonunu kanıtlayan tek bulgu serum kızamıkçık IgG antikor pozitifliğidir 6 . Sağlık çalışanlarında kızamıkçık riskinin diğer mesleklerle karşılaştırıldığında daha fazla olduğunu gösteren veri bulunmamaktadır ${ }^{1}$. Ancak Amerika Birleşik Devletleri'nde eliminasyon öncesindeki yıllarda yaşanan salgınlarda sağlık çalışanlarından duyarlı iş arkadaşlarına ve hastalara, hastalardan sağlık çalışanlarına ve diğer hastalara bulaşın olduğu bildirilmiştir ${ }^{7,8}$. Suçiçeği, varicella zoster virüsünün etken olduğu oldukça bulaşıcı bir döküntülü hastalıktır. Kişiden kişiye direk temas ve enfekte aerosollerinin inhalasyonu yolu ile bulaşmaktadır. Hastane ortamlarında sağlık çalışanları, hastalar ve ziyaretçiler nozokomiyal bulaş kaynaklarını oluşturmaktadırlar9

Çalışmamızda, sağlık çalışanlarında KKK ve suçiçeği hastalığına karşı hastalık geçirme öyküsünü hatırlamayanların oranını sirasiyla; $\% 32,9, \quad \% 42, \quad \% 26,4$ ve $\% 25,7$ olduğunu tespit ettik. Sağlık çalışanlarında çok merkezli yapılan bir çalışmada çalışmamız sonuçlarına benzer şekilde hastalık geçirme öyküsünü hatırlama oranları; kızamık \%32,4, kızamıkçık \%41,4, kabakulak \%23,4, ve suçiçeği $\% 25,3$ olarak bildirilmiştir ${ }^{10}$. Zencir ve arkadaşlarının 151 sağlık çalışanında yaptığı bir anket çalışmasında kızamık, kızamıkçık, kabakulak ve suçiçeği hastalığı geçirme durumunu hatırlamayanların oranlarını sirasiyla \%51, \%79, \%39, \%31 olarak verilmiştir ${ }^{2}$. Ülkemizde yapılan bir çok çalışmada kabakulak ve suçiçeği 
enfeksiyonlarının hatırlanma oranları diğerlerine göre daha yüksek tespit edilmiştir ${ }^{10,11}$. Japonya'da sağlık çalışanlarında yapılan bir çalışmada KKK ve suçiçeği hastalığına karşı hastalık öyküsünü hatırlamayanlar \%30-40 ve aşlama durumunu hatırlamayanlar ise $\% 60-70$ olarak bildirilmiştir ${ }^{12}$. Çalışmamızda sağlık çalışanlarının KKK ve suçiçeğine karşı karşılaşma durumlarını gösteren serolojik tetkikleri olmadığından hatırlama ile ilişkisi değerlendirilememiştir.

Kabakulak ve suçiçeği enfeksiyonlarının daha belirgin semptomlarla geçirilmesi hatırlanma oranlarının daha yüksek olması ile sonuçlanmaktadır. Ayrıca klinik bulguların net olması nedeniyle de kişiler ve aileler tarafından daha kolay hatırlanabilmektedir. Çalıșmamızda kabakulak ve suçiçeği hastalığı katılımcıların en çok hatırladıklarını ifade ettikleri hastalıklardı. İtalya'da sağlık çalışanlarında yapılan çok merkezli bir çalışmada KKK ve suçiçeği hastalığ öyküsü için pozitif prediktif değer \%95 oranında bulunmuștur ${ }^{13}$. Ülkemizde yapılan bir çalışmada ise KKK hastalık öyküsünün pozitif prediktif değeri \%92, suçiçeği için \%100 olarak bildirilmiștir ${ }^{14}$.

Ülkemizde çocukluk çağı aşılamaları düzenli olarak yapılmakta ve bebeklik kartları verilmektedir. $\mathrm{Bu}$ kartlarının kaybedilmesi, uygun şekilde saklanmaması yapılan aşıların hatırlanamaması ile sonuçlanmaktadır. Sağlık çalışanlarındaki aşı yaptırma öykülerini hatırlamama durumu kızamık, kızamıkçık, kabakulak ve suçiçeği aşısı için sırasıyla \%44 ve $\% 37,6$ idi. Zencir ve arkadaşlarının çalışmasında kızamık, kızamıkçık, kabakulak ve suçiçeği aşısı yaptırma durumlarını hatırlamayanların oranları sırasıyla $\% 51, \% 79$, $\% 39$, ve \%31 olarak bildirilmiștir ${ }^{2}$. Alp ve arkadaşlarının 1255 sağlık çalışanında yaptıkları çalışmada kızamık, kızamıkçık, kabakulak ve suçiçeği aşısı öykünün pozitif prediktif değeri sırasıyla $\% 96, \% 100, \% 93$ ve\%
98, negatif prediktif değeri ise sırasıyla \%13, $\% 5, \% 17$ ve $\% 2$ olarak bildirilmiștir ${ }^{15}$. Çalışmamızda sağlık çalışanlarının kendi öz değerlendirmeleri ile bildirilen hastalık ve aşılama öyküleri serolojik sonuçları ile karşılaştırılamadığından pozitif ve negatif prediktif değer belirlenemedi.

Sağlık personelinde kızamık veya kızamıkçık aşısı için öncesinde serolojik taramanın gerekli olmadığı gösterilmiştir². Bazı çalışmalarda ise sağlık çalışanına KKK aşılarının aşılanma durumlarını bilmeden aşılamanın maliyet etkin olmadığ $\breve{l}_{1}$ belirtilmektedir ${ }^{16,17}$. Ülkemizde seronegatif sağlık çalışanlarının aşıları Sağlık Bakanlığı tarafından ücretsiz olarak sağlanmaktadır. Buna karşın çalışmamız sonuçlarında katılımcıların önemli bir kısmında KKK ve suçiçeği aşısı yaptırma durumlarını bilmediklerini ve aşılanma oranlarının az olduğunu görmekteyiz.

Cılız ve arkadaşlarının çalışmasında sağlık çalışanlarının \%99,7'sinin kızamık, kabakulak ve suçiçeği antikorlarının pozitif, \%96,8'inin kızamıkçık antikor pozitifliği olduğunu bildirmişlerdir ${ }^{18}$. Başka bir çalışmada kızamıkçık seropozitifliği \%92,2, kabakulak $\% 98,2$ ve suçiçeği seropozitifliği $\% 94,3$ olarak bulunmuştur ${ }^{19}$. Çalışmamızda kızamık, kızamıkçık, kabakulak ve suçiçeğine karşı seropozitif olduğunu bildiren sağlık çalışanı oranları sirasiyla $\% 77,6, \% 81,5, \% 81,6$ ve \%83,6 idi. Kızamık oldukça bulaşıcı viral hastalıklardan biridir ve çeşitli komplikasyonlarla ilişkilidir. Artan seyahat ve yakın zamanda mülteci akımı nedeniyle çeşitli Avrupa ülkelerinde kızamık salgınları bildirilmiştir ${ }^{20,21}$. Ayrıca Teksas'da okul çocuklarında yapılan bir çalışmada düşük aşılanma oranlarının kızamık salgınlarına neden olacak kadar düşük olduğu bildirilmiştir ${ }^{22}$. Ülkemizde de 2012 yllında dışarıdan gelen olgularla başlayan ve içinde sağlık çalışanlarının da olduğu kızamık olgu sayılarında artış yaşanmıştır. ACIP salgınlar 
sırasında hastalı̆̆ın yayılmasının durdurulması amaciyla serolojik testlerle zaman kaybetmeden aşılamanın hızla yapılmasını önermektedir ${ }^{1}$.

Çok merkezli olarak yapılan bu çalışma sonucunda sağlık çalışanlarında KKK ve suçiçeği geçirme durumunu hatırlamayan ve geçirmedim diyenlerin sayısının fazla olmasına karşın aşı yaptırmayan personelin ise az olduğunu görmekteyiz. Aşı yaptırmayan personel sayısının fazla olması çocukluk döneminde hastalığın geçirilmesi ile ilişkilendirilebilir. KKK ve suçiçeği gibi bulaşıcı hastalıklar özellikle çocukluk yaş grubunda görülmesine karşın yetişkinler için de gelişebilecek komplikasyonlar açısından oldukça önemlidir ${ }^{23}$. Erişkin aşllaması, aşı ile önlenebilir hastalıkları önlemede ve mortaliteyi azaltmada önemli rol oynamaktadır ve düşük maliyetlidir. Fakat ülkemizde erişkin aşlama oranları oldukça düşüktür ${ }^{24}$. Sağlık çalışanlarında da durum farlı değildir. Yakın zamanda yapılan çok merkezli bir çalışmada sağlık çalışanlarında kızamık, kızamıkçık ve kabakulak aşılamasının çok fazla olmadığı bu durumu destekler niteliktedir ${ }^{3}$. Şengöz ve arkadaşlarının sağlık çalışanlarında yaptıkları çalışmada katılımcıların 71'inde $(\% 18,5)$ kızamık, kızamıkçık ve kabakulak aşısı olduğunu ve 28 'inde $(\% 7,3)$ suçiçeği aşısı olduğunu belirtmişlerdir ${ }^{19}$. Çalışmamızda da KKK aşısı yaptıran sağlık personeli 2713 (\%28) ve suçiçeği aşısı yaptıran katılımcı sayısı 785 (\%89) idi.

Sağlık çalışanları hastalarla doğrudan temas halinde olmaları sebebiyle bulaşıcı hastalıklara karşı hassastırlar ve bulaşıcı hastalıkların hastane yoluyla bulaşmasında rol oynayabilirler ${ }^{25}$. $\mathrm{Bu}$ nedenle sağllk çalışanlarının KKK ve suçiçeğine karşı bağışıklık durumları kontrol edilmeli ve kayıt altına alınmalıdır ${ }^{1}$. Çalışmamızda serolojik sonuçlarına baktırmayan sağlık çalışanlarının oranının fazla olması ülke genelinde eksikliğimizi ön plana çıkarmaktadır. Sağlık çalışanlarının serolojik değerlendirmeleri işe başlamadan önce kontrol edilmeli ve gerekli aşı programına alınmalıdır. Başta çocuk kliniği ve yeni doğan yoğun bakım üniteleri olmak üzere tüm duyarlı sağlık personeline KKK ve suçiçeği aşısı yapılmalıdır.

Teşekkür: Çalışmanın istatiksel analizinde desteği için Doç. Dr. Selçuk Nazik hocamıza teşekkürlerimizi sunarız.

Etik Kurul Kararı: Sağlık Bilimleri Üniversitesi İzmir Bozyaka Eğitim Araştırma Hastanesi Etik kurulu (Tarih: 08.09.2016 Sayı: 461) onayı ve Türkiye Halk Sağlığı Kurumu iznini takiben, ülke genelinde çok merkezli olarak online anket şeklinde gerçekleştirilen tanımlayıcı nitelikte bir araştırmadır.

Çıkar Çatışması Beyanı: Yazarlar çıkar çatışması olmadığını bildirmişlerdir.

Finansal Destek: Bu çalışma her hangi bir fon tarafından desteklenmemiştir.

Declaration of Conflicting Interests: The authors declare that they have no conflict of interest.

Financial Disclosure: No financial support was received.

\section{KAYNAKLAR}

1. Centers for Disease Control and Prevention: Immunization of health care personnel: recommendations of the Advisory Committee on Immunization Practices (ACIP). MMWR 2011; 60: 145.

2. Zencir M, Bal F, Guler M, et al. The evaluation of exposure status against the measles, mumps, rubella and the varicella zoster virüs infections among the health care workers. Izmir Training and Research Hospital Medical Journal 2014; 18: 108-12.

3. Mulholland EK, Griffiths UK, Biellik R. Measles in the 21st century. N Engl J Med. 2012; 366: 1755-7.

4. McLean HQ, Fiebelkorn AP, Temte JL, et al. Centers for Disease Control and Prevention. Prevention of measles, rubella, congenital rubella syndrome, and 
mumps, 2013: summary recommendations of the Advisory Committee on Immunization Practices (ACIP). MMWR Recomm Rep. 2013; 62: 1-34.

5. Çiçek ÇA, Duygu F. Şanlıurfa ilindeki doğurganlık çağındaki kadınlarda Rubella antikorlarının araştırılması: Üç yıllık değerlendirme. Dicle Med J 2012; 39: 174-8.

6. Plotkin SA, Reef SE. Rubella vaccine. In: Plotkin S, Orenstein W, Offit P, eds. Vacciness 5 th ed. Philadelphia, PA: W.B. Saunders. 2008: 735-71.

7. CDC. Rubella in hospital personnel and patientsColorado. MMWR. 1979;28: 325-7.

8. Polk BF, White JA, De Girolami PC, et al. An outbreak of rubella among hospital personnel. N Engl J Med. 1980; 303: 541-5.

9. CDC. Prevention of varicella: recommendations of the Advisory Committee on Immunization Practices (ACIP). MMWR 2007; 56.

10. Mert D, Tosun S, Yıldız IE, et al. Healthcare Workers' Exposures for Mumps, Measles, Rubella and Varicella Zoster Virus Infections: A multicenter Survey Study. JMID. 2019; 9: 144-9.

11. Guner E. Determination of awareness and immunization status of diseases and vaccination that can be protected by the health care workers. University of Health Sciences, Bozyaka Training and Research Hospital, Department of Infectious Diseases and Clinical Microbiology, Thesis, Izmir 2017.

12. Kumakura S, Onoda K, Hirose M. Self-reported histories of disease and vaccination against measles, mumps, rubella and varicella in health care personnel in Japan. J Infect Chemother. 2014; 20: 194-8.

13. Taddei C, Ceccherini V, Niccolai G, et al. Attitude to ward immunization and risk perception of measles, rubella, mumps, varicella and pertussis in health care workers in 6 hospitals of Florance, Italy 2011. Hum Vaccin Immunother. 2014; 10: 2612-22.

14. Celikbas A, Ergonul O, Aksaray S, et al. Measles, rubella, mumps, and varicella seroprevalence among health care workers in Turkey: is prevaccination screening cost-effective? Am J Infect Control. 2006; 34: 583-7.
15. Alp E, Cevahir F, Gokahmetoglu S, et al. Prevaccination screening of health care workers for immunity to measles, rubella, mumps, and varicella in a developing country: What do we save? J Infect Public Health. 2012; 5: 127-32.

16. Giri P, Basu S, Farrow D, et al. Cost-effectiveness analysis of MMR immunization in health care workers. OccupMed. 2013; 63: 422-4.

17. Chodick G, Ashkenazi S, Livni G, et al. Costeffectiveness of varicella vaccination of health care workers. Vaccine .2005; 17: 5064-72.

18. Ciliz N. Determination of measles, rubella, mumps, varicella, diphtheria, tetanus and HBV antibody levels in health care workers, Celal Bayar University Hospital, Department of Medical Microbiology, Thesis, Manisa 2013.

19. Sengoz M. Seroprevalence of measles, rubella, mumps, varicella in health care workers. Bulent Ecevit University Hospital, Department of Infectious Diseases and Clinical Microbiology, Thesis, Zonguldak 2015.

20. Muscat M, Shefer A, Ben Mamou M, et al. The state of measles and rubella in the WHO European Region, 2013. Clin Microbiol Infect. 2014; 20: 12-8.

21. Zipprich J, Winter K, Hacker J, et al. Centers for disease control and prevention (CDC). Measles outbreak-California, December 2014- February 2015. MMWR Morb Mortal Wkly Rep. 2015; 64: $153-4$.

22. Sinclair DR, Grefenstette JJ, Krauland MG, et al. Forecasted Size of Measles Outbreaks Associated With Vaccination Exemptions for School children. JAMA Network Open. 2019; 2: e199768.

23. Türkiye Enfeksiyon Hastalıkları ve Klinik Mikrobiyoloji Uzmanlık Derneği, Erişkin Bağışıklama Çalışma Grubu. Erişkin Bağışıklama Rehberi, 2019.

24. Türk Geriatri Derneği. Ulusal Aşı Çalıştayı Raporu. Ankara; 2014 March 27-9.

25. Andrew EC, Gibney KB, Denholm J, et al. Seroprotection to vaccine preventable diseases among workers at a Victorian tertiary hospital. Aust N Z J Public Health. 2016 Mar 30. 